\title{
Role of Postmortem Multislice Computed Tomography Scan in Close Blunt Head Injury
}

\author{
Prijo Sidipratomo ${ }^{1, *}$, Trijono Karmawan Sukana Prija ${ }^{2}$, Bachtiar Murtala $^{3}$, Agus Purwadianto ${ }^{4}$, \\ Gatot Susilo Lawrence ${ }^{5}$
${ }^{1}$ Postgraduate Program in Medicine, Faculty of Medicine, Hasanuddin University, Jl. Perintis Kemerdekaan Km.10, Makassar, Indonesia
${ }^{2}$ Department of Radiology, Faculty of Medicine, Airlangga University, Jl. Mayjen. Prof. Dr. Moestopo No.47, Surabaya, Indonesia
${ }^{3}$ Department of Radiology, Faculty of Medicine, Hasanuddin University, Jl. Perintis Kemerdekaan Km.10, Makassar, Indonesia ${ }^{4}$ Department of Forensic Medicine, Faculty of Medicine, University of Indonesia / Dr. Cipto Mangunkusumo Hospital, Jl. Salemba Raya No. 6, Jakarta, Indonesia
${ }^{5}$ Department of Forensic Medicine, Faculty of Medicine, Hasanuddin University, Jl. Perintis Kemerdekaan Km.10, Makassar, Indonesia \\ *Corresponding author. E-mail: sidipratomo@yahoo.com
}

\section{Abstract}

$\mathrm{B}$ ACKGROUND: Conventional autopsy in Indonesia is not well accepted as it is contrary to religion and culture. New radiological imaging method such as multislice computed tomography (MSCT) scan has potential to be a diagnostic tool in forensic pathology. The purpose of this study is to determine the ability of MSCT scan in finding abnormalities in close blunt head injury compared with autopsy.

METHODS: This study used descriptive qualitative method. Postmortem cases in Department of Foresic Medicine and Radiology of Dr. Cipto Mangunkusumo Hospital were selected based on inclusion criteria. Then MSCT scan and autopsy were conducted. MSCT scan and autopsy results were compared and analyzed.

RESULTS: There were 491 postmortem cases of blunt head injury. However, only 10 cases fulfilled inclusion criteria. Subarachnoid haemorrhages were identified 100\% with MSCT scan and 80\% with autopsy. Cerebral oedemas were identified $100 \%$ either with MSCT scan and autopsy. Subdural haemorrhages were identified $100 \%$ with MSCT scan, while $50 \%$ with autopsy. Multiple fractures were identified $80 \%$ with MSCT scan, while $40 \%$ with autopsy.

CONCLUSION: MSCT scan showed a sensitive detection in finding abnormalities in close blunt head injury. Therefore it could be as an alternative choice of examination in close blunt head injury cases.
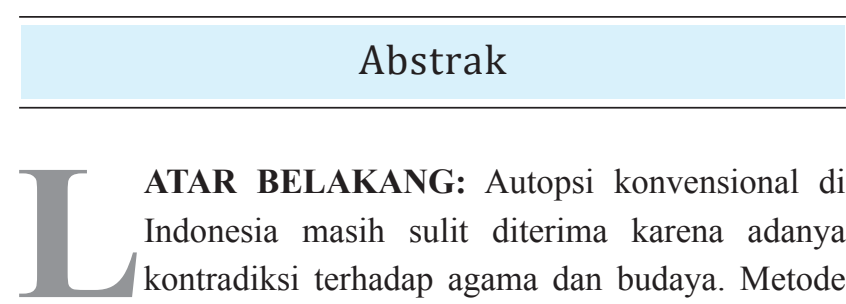

ATAR BELAKANG: Autopsi konvensional di Indonesia masih sulit diterima karena adanya kontradiksi terhadap agama dan budaya. Metode imaging radiologi baru seperti multislice computed tomography (MSCT) scan berpotensi sebagai salah satu alat diagnostik dalam patologi forensik. Tujuan dari penelitian ini adalah untuk mengetahui kemampuan MSCT scan dalam menemukan abnormalitas pada trauma tumpul kepala yang tertutup dibandingkan dengan autopsi.

METODE: Metode penelitian ini adalah deskriptif kualitatif. Kasus postmortem di Departemen Forensik dan Radiologi Rumah Sakit Cipto Mangunkusumo diseleksi berdasarkan faktor inklusi. Kemudian dilakukan MSCT scan dan autopsi. Hasil MSCT scan dan autopsi dibandingkan dan dianalisis.

HASIL: Didapatkan 491 kasus trauma tumpul kepala postmortem. Akan tetapi, hanya 10 kasus yang memenuhi kriteria inklusi. Perdarahan subarachnoid teridentifikasi $100 \%$ dengan MSCT scan dan 80\% dengan autopsi. Edema serebri teridentifikasi $100 \%$ baik dengan MSCT scan dan autopsi. Perdarahan subdural teridentifikasi 100\% dengan MSCT scan, dan hanya 50\% dengan autopsi. Fraktur multipel teridentifikasi 80\% dengan MSCT scan, sedangkan $40 \%$ dengan autopsi.

KESIMPULAN: MSCT scan memperlihatkan deteksi yang sensitif dalam menemukan abnormalitas pada trauma 
KEYWORDS: multislice computed tomography scan, postmortem, blunt head injury, autopsy

Indones Biomed J. 2014; 6(2): 101-6 tumpul kepala yang tertutup. Oleh karena itu, MSCT scan dapat sebagai pilihan alternatif pada kasus trauma tumpul kepala.

KATA KUNCI: multislice computed tomography scan, postmortem, trauma tumpul kepala, autopsi

\section{Introduction}

The importance of autopsy procedure has been widely recognized. Autopsy is the current gold standard for determining cause of death.(1-3) Evolution of medical science was heavily influenced by examination of corpses, a key method for description, characterization and understanding the function of human body and the effects of diseases on the target organs. From 1950 until now, several studies have contributed to the understanding of more than 80 pathologies (4) and considered to be a prerequisite for medical education and professional development.(5)

However, in recent years, the rate of autopsy decreased dramatically worldwide, from approximately $60 \%$ in 1960 to $10 \%$ or less in 2005 , both in the United States and Europe (6), with a minimum of 3.7\% in France in 1997 (7). Decreasing in autopsy rate is due to several factors, included : progress in diagnosis of diseases, particularly the development of advanced medical imaging methods such as computer tomography and nuclear magnetic resonance (8); the attitude of the deceased's family, which often opposes to autopsy (9). Some authors (10-13) suggest the reluctance of the forensic experts and pathologists to perform the autopsy, possibly due to infectious risk and time consumption.

The other limitation of autopsy is "subjective and observer-dependent", and cannot be used to provide a second opinion in court due to the fact that the body tissue are dissected and cannot be stored for a longer time except for selected parts or small specimens for histological examination.(14)

Lawrence and his Forensic-Medicolegal team of Faculty of Medicine, Hasanuddin University, in March 12, 2009, are the first in Indonesia to report the application of virtual autopsy as an alternative choice of the conventional autopsy. This method was selected as an acceptable method to conduct the scientific forensic investigation of the death of a servant with unknown cause. However, the CT scan used in 2009 was a conventional CT scan that could only provide 4 slices.(15)

We, in collaboration with the Forensic-Medicolegal team of Hasanuddin University, have also showed the virtual autopsy method as one of modalities to be used in scientific forensic investigation, in National Congress of Forensic Medicine-Medicolegal.(16)

The acceptance of virtual autopsy as the substitution of conventional autopsy is not easy to be accepted. For the eastern culture, virtual autopsy is still like a fresh air to solve the refusal conventioanal autopsy problem. The cost and benefit of virtual autopsy should be considered. There is another advantage of virtual autopsy, it is effective in determining kind of injury such as gunshot wounds, because it can be evaluated without breaking the structure of the body. The corpse can not be stored for a long time and dissected like usual .

Considering several limitations of autopsy, some studies were performed to overcome, such as evaluating some modalities which can help autopsy processing in determining cause of death. New radiological imaging method such as multislice computed tomography (MSCT) scan has potential to be a main diagnostic tools in forensic pathology. It is a kind of virtual autopsy, that can generate large, high quality data sets, 3 dimensions (3D), with submilimeter precision. Interactive visualization of these $3 \mathrm{D}$ data sets can provide valuable insight and enables noninvasive diagnostic procedures.(16)

There are many other reasons for increasing interest in virtual autopsy, for instance, they are time saving and more systematic. With virtual autopsy, the body remains intact, avoiding objections by family members or religious communities, and permitting additional analysis by other forensic pathologists on the same body, in effect, second or third diagnoses or opinions. Images and results of virtual autopsy are understandable for jurors in criminal cases. Furthermore infections that pose serious health risks for coroners, pathologists, and medical examination could be avoided. And finally virtual autopsy such as MSCT scan can be stored easily, conveniently and indefinitely.(17)

Postmortem MSCT scan of bodies prior to medicolegal autopsy has become a powerful tool in several forensic intitutes throughout the world. Indeed, there may be a number of advantages to perform a MSCT scan before a medicolegal autopsy. In forensic pathology as well as in clinical settings the investigation of head trauma is based 
on combined analysis of the present external lesions, cranial fractures and intracranial lesions. The scans of head are suitable to visualize lesions especially bone, some soft tissue and more cerebral pathologic changes or lesions. Fractures, intracranial haemorrhages and hematomas can be demonstrated either 2- and 3-dimensionally, providing a general overview of simple as well as complex lesions, e.g., gun-shot lesions or multiple fractures. However, especially minor lesions of the soft tissue, bone or intracranial lesions can be difficult to diagnose on MSCT scan which have to be kept in mind when investigating head injury and the corresponding injury mechanisms (18).

Imaging the posterior fossa of the brain is a challenge in computed tomography (CT) scanning. Because of the great difference in beam attenuation ability between the dense bone of the skull and less dense tissue of the brain, streak artifacts are common. This inherent limitation may be managed by decreasing slice thickness when scanning the posterior fossa and increasing the $\mathrm{kVp}$ setting.(19) Modern MSCT scanners allow studies of the head to be routinely acquired with thinner slices than in the past 1.25 $\mathrm{mm}$ thickness is typical. These thin slices help to reduce beam-hardening artifacts. Images are often merged into thicker slices for viewing. In examinations of the head, the helical CT mode is used mainly for the purpose of generating 3-dimensional reformations or to minimize motion-related artifacts. In general, routine head studies are performed using an axial mode, and CT angiography (CTA) studies of the head and neck are performed using a helical mode. MSCT scan is rapidly becoming the new standard in radiological imaging.(19)

Based on previous research reported in 2009 and 2010 in Makassar, current studies was conducted to evaluate the role of postmortem MSCT scan in blunt head injury. Indeed, the main purpose of this study is to assist conventional autopsy in finding abnormalities.

\section{Methods}

Descriptive qualitative research design was used in this study. This study was conducted in Department of Foresic Medicine and Radiology of Dr. Cipto Mangunkusumo Hospital from February 2013 to February 2014. The inclusion criteria were visum et repertum to perform autopsy and close blunt head trauma as cause of death. This study has been approved by Ethical Committe of Faculty of Medicine, Hasanuddin University (No. UH 11110321).

Inclusion criteria-fulfilled postmortem cases were examined by using both MSCT scan and conventional autopsy in finding abnormalities. All abnormalities which were found from both MSCT scan and conventional autopsy were compared and analyzed.

MSCT scan was obtained by spiral (helical) scan Somatom Definition (Siemens, Forchheim, Germany), with thickness of 1 and $5 \mathrm{~mm}$, increment 0.75 and 4 , pitch factor 1, kernel B31f, B50f, B70f, $120 \mathrm{kV}, 200 \mathrm{mAs}$, range: cranium scan and dual energy scan. Spiral /helical scanning is characterized by continuous gantry rotation and continuous data acquisition while the corpse's table is moving at constant speed.

\section{Results}

During the period, there were 491 postmortem cases of blunt head injury. However, many deceased's families rejected autopsy examination, therefore only 10 cases were obtained. Subjects were MSCT scan without contrast. MSCT scan results were read by 2 radiologists. Meanwhile the autopsy was performed by a forensic specialist. Common abnormalities including subdural haemorrhage, subarachnoid haemorrhage, intraparenchymal haemorrhage, subgaleal hematome, cerebral oedema, cerebellar oedema, brainstem oedema, pneumocephalus, uncal herniation, brainstem herniation, skull base fracture and multiple fractures were found with MSCT scan and autopsy (Table $1)$.

\section{Comparison of MSCT Scan and Autopsy Results}

Eight common abnormalities in traumatic brain injury obtained with MSCT scan and autopsy were compared and analyzed. The 8 abnormalities were subdural haemorrhage, subarachnoid haemorrhage, skull base fracture, multiple fractures, cerebral oedema, brainstem oedema, brainstem herniation, and pneumocephalus.

Table 2 shows that in comparison to autopsy, MSCT scans could sensitively identify abnormalities in these 10 postmortem cases.

\section{Discussion}

Subarachnoid haemorrhage and cerebral oedema in postmortem blunt head injury, are usually found in autopsy, could also be found with MSCT scan with similar results. Additionally, a report shows that sensitivity of MSCT scan for subarachnoid haemorrhage was $92.2 \%$, specificity was $100 \%$, negative predictive value was $99.4 \%$ and positive predictive value was $100 \%$.(21) Thus, for the cause of death 
Table 1. MSCT Scan and Autopsy Results. Ten cases of postmortem in blunt head injury were MSCT scanned and autopsied.

\begin{tabular}{|c|c|c|}
\hline Case & MSCT Scan & Autopsy \\
\hline Case 1 & $\begin{array}{l}\text { Subdural haemorrhage at posterior fossa, subarachnoid haemorrhage, site } \\
\text { of brainstem haemorrhage, cerebral oedema, cerebellar oedema, } \\
\text { pneumocephalus, skull base fracture, uncal herniation. }\end{array}$ & $\begin{array}{l}\text { Subdural haemorrhage (at posterior fossa), } \\
\text { subarachnoid haemorrhage, cerebral } \\
\text { oedema, site of brainstem haemorrhage. }\end{array}$ \\
\hline Case 2 & $\begin{array}{l}\text { Subdural haemorrhage at posterior fossa, subarachnoid haemorrhage, } \\
\text { intraparenchymal haemorrhage, site of brainstem haemorrhage, cerebral } \\
\text { oedema, pneumocephalus, brainstem herniation, fracture of the right and } \\
\text { left petrous bone, cerebellar oedema, posterior fossa fracture, fracture of the } \\
\text { right and left temporal bone. }\end{array}$ & $\begin{array}{l}\text { Subdural haemorrhage (at posterior fossa), } \\
\text { subarachnoid haemorrhage, cerebral } \\
\text { oedema, fractures of the (right and left) } \\
\text { petrous bone, the burst of a partial lobe at } \\
\text { cerebral, cerebellar, and brainstem. }\end{array}$ \\
\hline Case 3 & $\begin{array}{l}\text { Subdural haemorrhage at posterior fossa, subarachnoid haemorrhage, site } \\
\text { of brainstem haemorrhage, cerebral oedema, cerebellar oedema, brainstem } \\
\text { oedema, pneumocephalus, skull base fracture, posterior fossa fracture. }\end{array}$ & $\begin{array}{l}\text { Subdural haemorrhage (at posterior fossa), } \\
\text { subarachnoid haemorrhage, cerebral } \\
\text { oedema, site of brainstem haemorrhage, } \\
\text { skull base fracture. }\end{array}$ \\
\hline Case 4 & $\begin{array}{l}\text { Subdural haemorrhage at posterior fossa, subarachnoid haemorrhage, } \\
\text { extensive intracerebellar haemorrhage, cerebellar intraparenchymal } \\
\text { haemorrhage, cerebral oedema, cerebellar oedema, brainstem oedema, } \\
\text { brainstem herniation, pneumocephalus, posterior fossa (occipitale bone) } \\
\text { fracture, skull base fracture. }\end{array}$ & $\begin{array}{l}\text { Subdural haemorrhage (at posterior fossa), } \\
\text { subarachnoid haemorrhage, cerebral } \\
\text { oedema, brainstem haemorrhage, } \\
\text { cerebellar oedema. }\end{array}$ \\
\hline Case 5 & $\begin{array}{l}\text { Subdural haemorrhage at posterior fossa and the right frontal region, } \\
\text { subarachnoid haemorrhage, site of brainstem haemorrhage, cerebral } \\
\text { oedema, cerebellar oedema, brainstem oedema, pneumocephalus. }\end{array}$ & 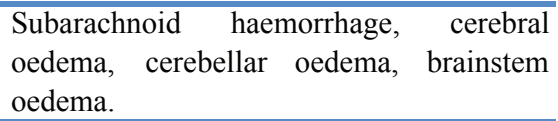 \\
\hline Case 6 & $\begin{array}{l}\text { Subdural haemorrhage at posterior fossa, subarachnoid haemorrhage, } \\
\text { brainstem haemorrhage, brainstem oedema, cerebellar oedema, cerebral } \\
\text { oedema, pneumocephalus, multiple fractures: fractures of the right and left } \\
\text { frontal bone, fractures of the right and left posterior fossa, skull base } \\
\text { fracture, fracture of the left mastoid bone. }\end{array}$ & $\begin{array}{l}\text { Subdural haemorrhage (at posterior fossa), } \\
\text { subarachnoid haemorrhage, cerebral } \\
\text { oedema, cerebellar oedema, cerebellar } \\
\text { contusion, brainstem haemorrhage. }\end{array}$ \\
\hline Case 7 & $\begin{array}{l}\text { Subdural haemorrhage at posterior fossa, subarachnoid haemorrhage, site } \\
\text { of brainstem haemorrhage, cerebral oedema, cerebellar oedema, brainstem } \\
\text { oedema to the posterior fossa extensive pneumocephalus broad, multiple } \\
\text { fractures: skull base fracture, bilateral fractures of the orbital base and the } \\
\text { left frontal bone. }\end{array}$ & $\begin{array}{l}\text { Subarachnoid haemorrhage, cerebral } \\
\text { oedema, brain setem oedema, cerebellar } \\
\text { oedema, bilateral fractures of the orbital } \\
\text { base and the left frontal bone. }\end{array}$ \\
\hline Case 8 & $\begin{array}{l}\text { Subdural haemorrhage at posterior fossa, the right intracerebellar } \\
\text { haemorrhage, cerebral oedema with widespread narrowing systerna } \\
\text { especially systerna prepontin system in the brainstem. Multiple fractures: } \\
\text { skull base fracture, fracture of the right and left posterior fossa, linear } \\
\text { fracture at the right and left of sphenoid bone with pneumochepalus in the } \\
\text { left temporal region, pneumocephalus in the posterior fossa. }\end{array}$ & $\begin{array}{l}\text { Subarachnoid haemorrhage, fractures of } \\
\text { occipitoparietal bone, temporal bone, } \\
\text { sphenoid bone, and zygomaticum bone, } \\
\text { cerebral oedema. }\end{array}$ \\
\hline Case 9 & $\begin{array}{l}\text { Subdural haemorrhage at posterior fossa, subarachnoid haemorrhage, site } \\
\text { of brainstem oedema, cerebellar haemorrhage, cerebral oedema with } \\
\text { widespread narrowing sisterna especially sisterna prepontin system in the } \\
\text { brainstem, linear fracture at the right and left of sphenoid bone with } \\
\text { pneumochepalus in the left temporal region. }\end{array}$ & $\begin{array}{l}\text { Linear fracture at the right and left of } \\
\text { sphenoid bone. Extensive cerebral oedema }\end{array}$ \\
\hline Case 10 & $\begin{array}{l}\text { Subdural hematome in the fronto-temporo-parietal (causing midline shift), } \\
\text { subarachnoid haemorrhage, site of brainstem haemorrhage, cerebral } \\
\text { oedema, cerebellar oedema, subgaleal hematome in the left of } \\
\text { temporoparietal region, cranium bone fracture. }\end{array}$ & Cerebral oedema, cranium bone fracture. \\
\hline
\end{tabular}

related to subarachnoid haemorrhage and cerebral oedema in blunt head injury, MSCT scan could be considered as an option for finding these complications.

Bleeding is fatal, especially if it is accompanied by subarachnoid and subdural haemorrhages. A report shows that combination of subdural and subarachnoid haemorrhage is the leading cause of death for craniocerebral blunt head injury, which found more than half the cases.(22,23) From our current study, all 10 postmortem cases of blunt head injury subdural haemorrhage were found with MSCT scan, while 5 cases found with autopsy. So, this suggested that MSCT scan is sensitive enough in finding subdural haemorrhage.

Skull base and multiple fractures in blunt head injury were accompanied with tissue damages, which usually depend on the magnitude of fracture caused mechanical strength. Multiple fractures are usually caused by a large mechanical strength compared to the linear fracture. Skull 
Table 2. Comparison of MSCT Scan dan Autopsy in finding Abnormalities.

\begin{tabular}{lrcrc}
\hline \multirow{2}{*}{\multicolumn{1}{c}{ Abnormality }} & \multicolumn{2}{c}{ MSCT Scan } & \multicolumn{2}{c}{ Autopsy } \\
\cline { 2 - 5 } & \multicolumn{1}{c}{ Detected } & Undetected & Detected & Undetected \\
\cline { 2 - 5 } & \multicolumn{1}{c}{$\mathbf{N}(\%)$} & N(\%) & N(\%) & N(\%) \\
\hline Skull Base Fracture & $7(70 \%)$ & !"\#!\$\& & $4(57 \%)$ & $6(60 \%)$ \\
Multiple Fratures & $8(80 \%)$ & $2(20 \%)$ & $4(40 \%)$ & $4(40 \%)$ \\
Subarachnoid Haemorrhage & $10(100 \%)$ & $0(0 \%)$ & $8(80 \%)$ & $2(20 \%)$ \\
Subdural Haemorrhage & $10(100 \%)$ & $0(0 \%)$ & $5(50 \%)$ & $5(50 \%)$ \\
Cerebral Oedema & $10(100 \%)$ & $0(0 \%)$ & $10(100 \%)$ & $0(0 \%)$ \\
Brainstem oedema & $6(60 \%)$ & $4(40 \%)$ & $2(20 \%)$ & $8(80 \%)$ \\
Brainstem Herniation & $1(10 \%)$ & $9(90 \%)$ & $0(0 \%)$ & $10(100 \%)$ \\
Pneumocephalus & $9(90 \%)$ & $1(10 \%)$ & $0(0 \%)$ & $10(100 \%)$ \\
\hline
\end{tabular}

base fracture is usually fatal due to the location adjacent to brainstem as a vital organ in the brain. Skull base and multiple fractures are usually highly correlated with the incidence of intracranial haemorrhage, including subarachnoid haemorrhage. alvaria were involved in $69.3 \%$ cases while comminuted fracture of the skull was common among the fatal cases. Skull base fracture was noted only in the fatal cases and a combination of subdural and subarachnoid haemorrhage was found in the majority of the fatal cases $(20,24)$. Identification of skull base and multiple fractures in this study were also found with MSCT scan. In addition, the radiology was reported superior to autopsy in assessing fracture.(14) In our current research, MSCT scan is superior to autopsy to visualize fracture. MSCT scan could be useful in assessing fracture, especially skull base fracture, which is difficult to be identified by conventional autopsy.

Abnormalities in blunt head injury detected with autopsy can be also detected with MSCT scan. MSCT scan has advantages which help autopsy to identify fracture, fatal haemorrhage, brainstem oedema and pneumocephalus. In addition, MSCT scan as a diagnostic modality, can perform faster and avoid contamination to the operator. Therefore, when autopsy could not be performed for some reasons, such as deceased's family refusal to act of the autopsy, pricewise, transmission of blood-borne pathogens at the time of autopsy on the corpse, MSCT scan will be taken into consideration in determining the cause of death.(813)Both MSCT scan and conventional autopsy have their own respective advantages. Thus, in this study, MSCT scan capabilities in finding the abnormalities found with autopsy were analyzed. Results suggest that MSCT scan with some of the highlights can be used as a complement or alternative to help autopsy in finding abnormalities.

\section{Conclusion}

In summary, our study has shown that MSCT scan has many advantages in assessing fractures, type of fatal haemorrhage, brainstem oedema and pneumocephalus. So that, If MSCT scan could be an alternative choice to help autopsy examination to identify cause of death in blunt head injury cases.

\section{Acknowledgement}

We would like to thank the forensic specialist and colleagues at the Department of Forensic Medicine, Faculty of Medicine, University of Indonesia / Dr. Cipto Mangunkusumo Hospital, Jakarta. We also thank to the radiologist and colleagues at the Department of Radiology, Faculty of Medicine, University of Indonesia / Dr. Cipto Mangunkusumo Hospital, Jakarta, for their commitment and support. Furthermore, we thank to the colleagues in postgraduate program in Hasanuddin University for their valuable contribution.

\section{References}

1. Shojana KG, Burton EC, McDonald KM, Goldman L. Changes in rates autopsy-detected diagnostic errors over time: a systematic review. JAMA. 2003; 289: 2849-56.

2. Loughrey MB, McCluggage WG, Toner PG. The declining autopsy rate and clinicians' attitudes. Ulster Med J. 2000; 69: 83-9.

3. Mitka M. CT, MRI scans offer new tools for autopsy. JAMA. 2007; 298: 392-3. 
4. Hill RB, Anderson RE. The autopsy-medical practice and public policy. Stoneham: Butterworth Publishers; 1988.

5. Roulson J, Benbow EW, Hasleton PS. Discrepancies between clinical and autopsy diagnosis and the value of post mortem histology; a meta-analysis and review. Histopathology. 2005; 47: 551-9.

6. Chariot P, Witt K, Pautot V, Porcher R, Thomas G, Zafrani ES, et al. Declining autopsy rate in a French hospital: physician's attitudes to the autopsy and use of autopsy material in research publications. Arch Pathol Lab Med. 2000; 124: 739-45.

7. Spiliopoulou C, Papadodima S, Kotakidis N, Koutselinis A. Clinical Diagnoses and Autopsy Findings: A Retrospective Analysis of 252 Cases in Greece. Arch Pathol Lab Med. 2005; 129: 210-4.

8. Combes A, Mokhtari M, Couvelard A, Trouillet JL, Baudot J, Hénin $\mathrm{D}$, et al. Clinical and Autopsy Diagnoses in the Intensive Care Unit. Arch Intern Med. 2004; 164: 389-92.

9. Maris C, Martin B, Creteur J, Remmelink M, Piagnerelli M, Salmon I, et al. Comparison of clinical and post-mortem findings in intensive care unit patients. Virchows Arch. 2007; 450: 329-33.

10. Haber SL. Whither the autopsy? Arch Pathol Lab Med. 1996; 120: 714-7.

11. Lundberg GD. College of American Pathologists Conference XXIX on restructuring autopsy practice for health care reform: let's make this autopsy conference matter. Arch Pathol Lab Med. 1996; 120: 736-8.

12. Marwick C. Pathologists request autopsy revival. JAMA. 1995; 273: 1889-91.

13. Scott K. Is the autopsy dead? ACP News Winter. 2002; 11: 19-21.

14. Yen K, Lövblad KO, Scheurer E, Ozdoba C, Thali MJ, Aghayev E, et al. Post-mortem forensic neuroimaging: Correlation of MSCT and MRI findings with autopsy results. Forensic Sci Int. 2007; 173: 2135 .

15. Lawrence GS, Chandra G, Mauluddin, Mathius D, Arkipus, Dase J. Virtual Autopsy as an alternative for conventional autopsy in a special conditional situation. Makassar: Forensic Scientific Meeting; 2009.

16. Prijo S, Chandra G, Lawrence GS. Pemanfaatan CT-Scan Dalam Bidang Forensic. Makassar: Kongres Nasional Perhimpunan Dokter Forensik Indonesia; 2010.

17. Kadarmo DA. Prosedur medikolegal penolakan otopsi ditinjau dari sudut pandang penyidik. Jakarta: Fakultas Kedokteran Universitas Indonesia; 2005.

18. Persson A. Virtual autopsy in Forensic Medicine. Science. 2008; 4: 60-3.

19. Vogl TJ, Harth M. Neuroimaging of The Posterior Fossa. Frankfurt: Department of Radiology, University of Frankfurt; Chapter 3. 1-15

20. Thali MJs, Yen K, Schweitzer W, Vock P, Boesch C, Ozdoba C, et al. Virtopsy-A New Imaging Horizon in Forensic Pathology: Virtual Autopsy by Postmortem Multislice Computed Tomography (MSCT) and Magnetic Resonance Imaging (MRI)-a Feasibility Study. J Forensic Sci. 2003; 48: 386-403.

21. Perry JJ, Stiell IG, Siviotti ML, Bullard MJ, Emond M, Symington C, et al. Sensitivity of Computed Tomography Performed within Six Hours of Onset of Head for Diagnosis of Subarachnoid Haemorrhage: Prospective Cohort Study. BMJ. 2011; 343: d4277. doi: $10.1136 /$ bmj.d4277.

22. Jacobsen C, Bech BH, Lynnerup N. A comparative study of cranial, blunt trauma fractures as seen at medicolegal autopsy and by computed tomography. BMC Med Imaging. 2009; 9: 18. doi: 10.1186/1471-2342-9-18.

23. Patil MA, Vas WF. Pattern of Fatal Blunt Head Injury: A Two Year Retrospective/ Prospective Medico Legal Autopsy Study. J Indian Acad Forensic Med. 2004; 32:144-9.
24. Chattopadhyay S, Tripathi C. Skull Fracture and haemorrhage pattern among fatal and nonfatal head injury assault victims-a critical analysis. J Inc Violence Res. 2010; 2: 99-102. 